OPEN ACCESS

Edited by:

Orsolya Valkó,

Centre for Ecological Research, Hungarian Academy of Sciences,

Hungary

Reviewed by:

Andrew M. Song,

University of Technology Sydney,

Australia

Philippe Le Billon,

University of British Columbia,

Canada

*Correspondence:

Juan He

juanhe@situ.edu.cn

Specialty section:

This article was submitted to

Conservation and Restoration

Ecology,

a section of the journa

Frontiers in Ecology and Evolution

Received: 15 September 2021

Accepted: 31 January 2022

Published: 03 March 2022

Citation:

He J and Zhang X (2022) China Revamping Decades-Old Fisheries Law to Combat Illegal, Unreported, and Unregulated Fishing: Stimulating the Intersection of Law, Technology,

and Markets.

Front. Ecol. Evol. 10:777497.

doi: 10.3389/fevo.2022.777497

\section{China Revamping Decades-Old Fisheries Law to Combat Illegal, Unreported, and Unregulated Fishing: Stimulating the Intersection of Law, Technology, and Markets}

\author{
Juan $\mathrm{He}^{1 *}$ and Xiong Zhang ${ }^{2}$ \\ 1 KoGuan Law School, Shanghai Jiao Tong University, Shanghai, China, ${ }^{2}$ State Key Laboratory of Biocontrol, School \\ of Ecology, Sun Yat-sen University, Shenzhen, China
}

As the world's leading fish producer, exporter and consumer State, China must act decisively to eradicate national and international commerce in wild-capture species derived from illegal, unreported, and unregulated (IUU) fishing. In 2019 China launched an overhaul of its 1986 Fisheries Law with a draft statute subject to the deliberation of the National People's Congress. In this policy brief, we argue that China should not miss the opportunity but proactively align with the global paradigm shift toward responsible and sustainable fisheries management. To amend the patchy legal framework and implement the rule of law ahead, we suggest technology-enabled traceability and market-responsive solutions to help the country mitigate illicit capturing, processing, and transaction events infiltrating from bait to plate.

Keywords: IUU fishing, China, Fisheries Law, supply chain management, digital traceability, seafood market

\section{INTRODUCTION}

Illegal, unreported, and unregulated (IUU) fishing is defined by the Food and Agricultural Organization (FAO) of the United Nations (UN) to encompass fishing activities: (1) in violation of applicable national, regional, and international laws, regulations or measures on the conservation and management of fisheries; (2) not reported or misreported to relevant national authorities or regional fisheries management organizations (RFMOs); and (3) conducted by stateless vessels, vessels (re)flagged to non-parties to RFMOs, for stocks or in areas where no competent RFMOs function, except for general international law contravened (FAO, 2001). Despite the broad consensus, IUU fishing continues to proliferate in pattern and magnitude worldwide, posing a daunting challenge for qualitative assessment on a global scale. One of the most cited estimates is Agnew et al. (2009) that IUU-caught fish was 11-19\% of reported catches, translating to 11-26 million tons valued at US\$10-23.5 billion in 2003. Packard Foundation (2020) provides the latest account, adapted from Watson and Tidd (2018), that IUU catches accounted for approximately $25 \%$ of global landings or 32 million tons in 2015, which had stabilized in more recent years.

In need of an updated analysis, the FAO calls for more robust and transparent estimates, with two critical suggestions provided to member States: (1) Efforts are more likely to be usefully focused on generating estimates at sub-national, national or regional levels; and (2) Indicators to monitor progress could be reflected by the numbers of vessels on RFMOs' IUU fishing vessel lists and 
included in the European Union (EU) "yellow" and "red" card lists, respectively (Macfadyen et al., 2016). Furthermore, a requisite toolbox of guiding principles and technical methodologies are developed to help monitor IUU fishing down to the state level (FAO, 2018).

Orientating toward a locally nuanced understanding of IUU fishing is opportune for China as the world's largest fisheries economy in terms of capture, production and export (FAO, 2020). Since it is the most important fishing nation on the planet, China must evolve from a significant cause to a potential solution to illegal and unsustainably sourced seafood on the global arena. Existing studies are not lacking in stressing China's fisheries management improvement on the supply side (Xue, 2006; Mallory, 2013; Pauly et al., 2014; Gutiérrez et al., 2020; Shen and Huang, 2020). This policy paper extends to a full chain lens, drawing upon the rapid development of information and communication technologies as well as seafood market dynamics. China's top fisheries statute and supportive sub-laws are being carefully refined, incorporating new mechanisms to ensure seafood's origin and transactions are increasingly transparent. We see this as a promising start to advance to government-led and even digital supply chain management to integrate seafood safety, security, and sustainability concerns into the fabric of traceability. Despite the lack of a universally agreed notion, we define seafood traceability governance for this study as the system or tool that makes the flow of seafood information possible through specified stages of production, processing, distribution, and sale (i.e., trackable), and allows for such records of production and product movement to be accessible at a future date and distant places (i.e., traceable).

\section{A WIDESPREAD AWAKENING TO ILLEGAL, UNREPORTED, AND UNREGULATED FISHING INSIDE AND OUTSIDE CHINA}

China's involvement in and level of due diligence to IUU supplies were not well documented until the last 10 years, building upon a growing mixture of publicly available (e.g., governmental, institutional websites, and publications), independently collected (e.g., expert surveys and interview-based fieldwork) and technically generated (e.g., Vessel Monitoring System/VMS, Automatic Identification System/AIS, and related satellite inputs) sources of materials. Although IUU fishing has troubled China's marine fisheries management as early as the 1950s, it is only from 2006 that China's law enforcement authorities began to seriously combat domestic IUU fishing through the "Special Law-Enforcement Campaigns for Marine Fisheries during the Summer Moratorium" (Zhang and Vincent, 2020). Such effort was further supported by China's Supreme Court which started launching criminal suits specifically against IUU fishing in 2016. In 2020, about 280 criminal cases of domestic IUU fishing were heard, leading to approximately 1,700 fishing boats confiscated or punished (China Coast Guard, 2021). However, such legal responses merely covered the summer moratorium for a long time. Without a central state repository, it remains dubious if China adequately comprehends the incidence and scale of IUU fishing that falls under its jurisdiction, let alone properly discharges international publicity obligations. Distinct terminologies (e.g., species names), data collection methodologies (e.g., bottom-up or top-down) and geographical demarcation applied in fisheries management (e.g., China's claimed share of exclusive economic zones/EEZs in disputed seas) have further complicated knowledge sharing. With few officially verified profiles, most existing studies remain fragmented and speculative. Bearing in mind those restraints, they can still be regarded as valuable and complementary estimates to complete the puzzle altogether. Provided below is a straightforward synthesis of pre-existing international scorings and surveys pertinent to China's performance in combatting IUU fishing:

- China received the worst IUU score out of 152 coastal states based on 40 indicators and assessed by fisheries experts for the IUU Fishing Index to benchmark countries' vulnerability, prevalence and response to IUU fishing. Its performance was considered particularly poor in discharging flag, port and overall State responsibilities (Macfadyen et al., 2019).

- China received an overall score of 0.37 in 2018, placing it at the 35th place among 40 countries assessed under the Fisheries Management Index which relied on expert surveys to rate fisheries management effectiveness on a stock-by-stock basis (Packard Foundation, 2020).

- China received a failing score among over half of 33 countries representing the top $90 \%$ of the world fish catch and evaluated for ecosystem-based fisheries management across the three parameters of principles, criteria and implementation steps (Pitcher et al., 2009).

- With data extracted from the FishSpektrum Krakken database and AIS for 2017 and 2018, at least 183 vessels in China's distant-water fishing (DWF) fleet were suspected or confirmed to be involved with IUU fishing. Numbers included state-owned DWF vessels and 104 vessels flagged outside China (Gutiérrez et al., 2020).

- Five Chinese-flagged or -owned vessels remain, as of the time of this writing, under the Combined IUU Fishing Vessel List which aggregates IUU vessel listings from twelve RFMOs and the International Criminal Police Organization (Trygg Mat Tracking, 2022).

- Drawing data from global institutions and existing reviews, China was considered to have provided the largest sum of harmful capacity-enhancing subsidies (e.g., fuel subsidies, tax exemptions, and vessel construction) valued at $\$ 16,637.7$ million, contributing to $47.5 \%$ of global subsidy value in 2016 (Arthur et al., 2019).

- The United States identified China as a third country with flagged vessels engaged in IUU fishing in 2009, issuing a yellow card that stayed for 22 months (Hosch, 2016). The 2019 report of the United States reserved concerns about China's fishing practices though it was no longer listed (National Oceanic and Atmospheric Administration, 2019). 
Here we present a brief bibliometric survey to facilitate the understanding of how IUU fishing has been studied and addressed by China, while a more in-depth and systematic review is warranted but beyond the scope of this brief. Because of non-transparency and data discrepancies, most scholarly studies have focused on specific sectors or species where China leads the world in production, processing or consumption (e.g., Hanson et al., 2000; Sadovy et al., 2017). The FAO recommends that more diverse and credible indicators must be explored to benchmark a state's relative status within a broad spectrum of IUU-related activities. In China's case, first, we conducted an online search to identify how its regulatory responsibilities to curb IUU fishing have been recognized in official documents. We used relevant keywords in Chinese (“海洋非法捕捞”, “海洋违 规渔船”, “禁止捕捞”, “海洋三无渔船” and “IUU”) to search national political and legal documents from the website of China' Ministry of Agriculture and Rural Affairs, ${ }^{1}$ and the online law archives hosted by Peking University. ${ }^{2}$ The search resulted in a total of 193 documents from which we identified 19 IUU-relevant policies ad laws. Second, we searched in Chinese and international peer-reviewed literature to examine the extent of issue awareness by the number of studies and the interest scope by keyword. To this end, we used "IUU" and "China's policy/policies" as the topic keywords to search peer-reviewed English literature from the Web of Science and the same keywords in title from Google Scholar. The search ended up with a total of three papers we found that directly addressed China's policy on IUU fishing. Additionally, we used similar topic keywords in Chinese to search peer-reviewed Chinese literature (Full text = “三无渔船” or “非法捕拹” + Full text = “海洋” and “我国” + Full text = “政策” or “管理” + Full text = "IUU” and “我国”) from China National Knowledge Infrastructure. The search reverted with 129 articles, where we found 27 articles that addressed the same topic of interest.

Apart from a numeric illustration in Figure 1, the keywords applied by the identified literature sources are summarized by frequency in Figure 2. We also categorize the identified Chinese official documents into 12 keyword clusters with frequency shown in Figure 3. Viewed together, the surveys present three main findings. Firstly, both Chinese governmental and scholarly awakening to IUU fishing is growing fast, outstripping international studies focused on China's role in IUU fishing ( $N=19,27$, and 3 in China's policy documents, Chinese and international literature, respectively in Figure 1). Although this is not surprising, it highlights the importance to comprehensively review Chinese policy documents and literature to truly understand how China has been viewing and addressing IUU fishing. Secondly, despite a growing interest in various management tools, China's academic studies and national policies have paid limited attention to international regulatory alignment to date (e.g., traceability, port state measures, and international agreement ratification in Figure 2). Thirdly, it follows that China has been keener on developing fishery management tools to address illegal fishing, as a subset of IUU fishing, in violation

${ }^{1}$ www.moa.gov.cn

${ }^{2}$ www.pkulaw.com

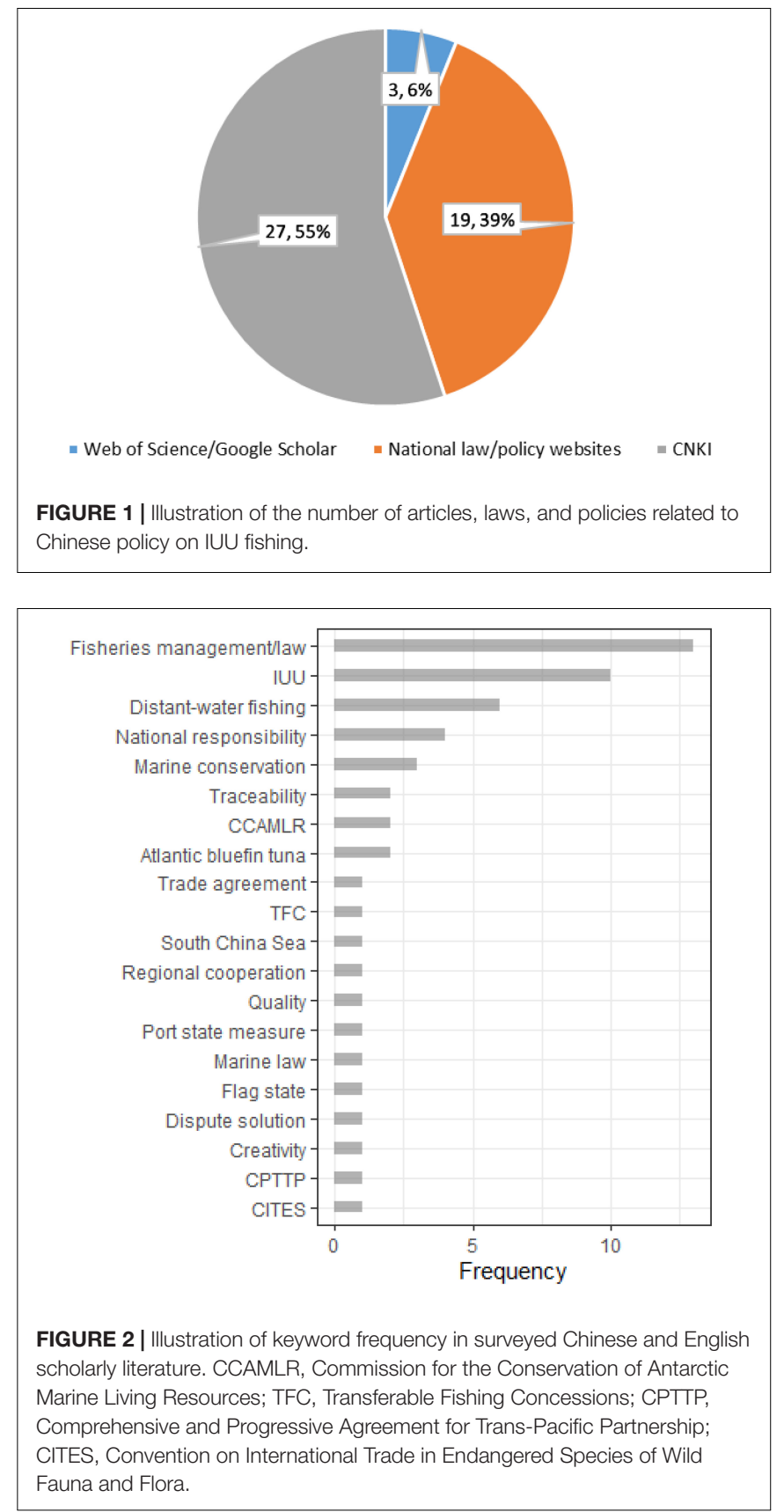

of its own national rules in domestic waters (e.g., fishing gear regulation, vessel management, and summer moratorium in Figure 3) than on regulating its distant-water fishing (DWF).

\section{A CRITICAL ASSESSMENT OF AMENDED LEGAL PROVISIONS TO COMBAT ILLEGAL, UNREPORTED, AND UNREGULATED FISHING}

For the passing decade, international legal liabilities, political tensions and ecological degradation realities have pressed hard 


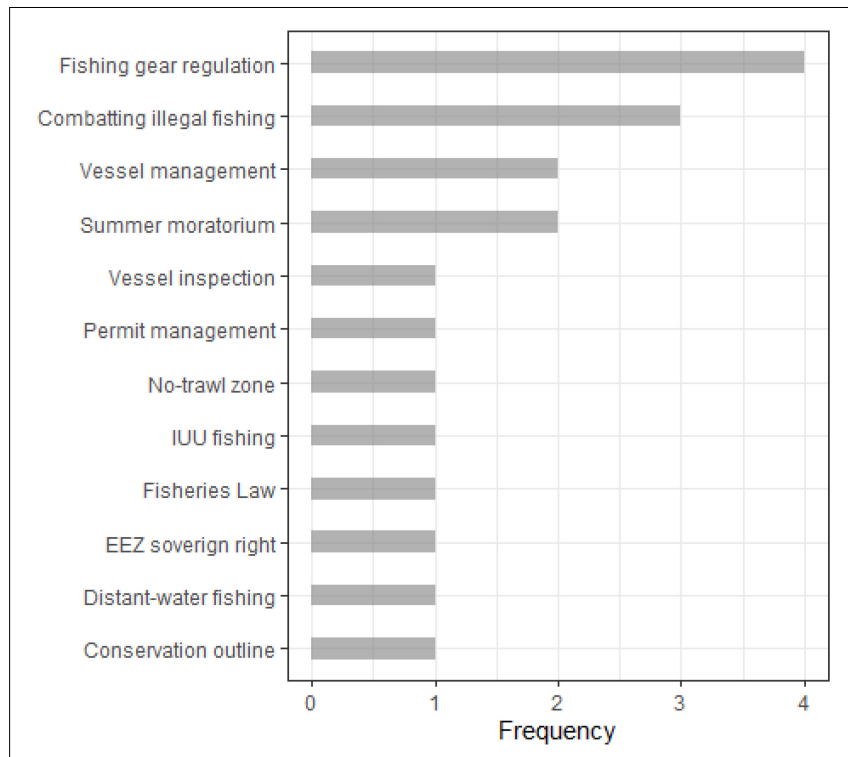

FIGURE 3 | Illustration of keyword frequency in surveyed Chinese laws and policies.

for China to consider rebalancing its agricultural modernization goals ("three rural" policy: agriculture, rural areas, and farmers) with ecological civilization imperatives. The latter were formally endorsed in the 13th National Five-Year Plan (2016-2020), echoed by a specific Marine Ecological Civilization Plan and the pledge for a Maritime Community with a Shared Future under the Belt and Road Initiative (BRI) (Packard Foundation, 2019). The 2015 UN Sustainable Development Goals underpinned by economic, environmental and social evaluation pillars are set to influence the modernization of China's sectoral laws. The top Fisheries Law, administered by the Fisheries Bureau under the Ministry of Agriculture and Rural Affairs (MARA), came to life in 1986. It has been revised four times between 2000 and 2013. Having undergone reassessment and revision since mid-2019, the new statute was later submitted for the deliberation of the National People's Congress (MARA, 2019b). Pending its final adoption, it is noteworthy that sustainability and conservation are explicitly enshrined as the new compass for direction to transform Chinese fisheries (MARA, 2019b, Arts 1 and 4). The old principle of rational exploitation exists to unleash the potential of aquaculture, mariculture, and recreational fisheries to satisfy a growing consumer demand (MARA, 2019b, Art 3). Conversely, freshwater and marine capturing, especially DWF, are brought under more stringent scrutiny and capacity controls than before. A shifted strategy aims to charter a new course of legal action to identify and punish IUU fishing involving Chinese actors (MARA, 2019b, Arts 65 and 74; MARA, 2020c, Art 33).

In all, the proposed amendment will convert the statute into eight chapters that span a total of 83 provisions. Among the others, Chapter 4 provides for targeted measures at IUU fishing, and Chapters 6 and 7 clarify supervision and management bodies and legal liabilities for IUU violators, respectively. Despite a missing national anti-IUU plan of action to echo the FAO's call (He, 2016), the article investigates the new normative space for China to actively respond to IUU fishing ahead. In line with the FAO's integrity approach (FAO, 2001), the normative survey is embedded in China's coastal, flag, port and market State responsibilities to prevent, deter, and eliminate IUU fishing. The legal provisions most relevant to China's state responsibilities to curb IUU fishing are classified in Table $\mathbf{1}$ below.

The illustration below reveals that, to some extent, China has begun to re-think its attitude and approach to the widespread problem of IUU fishing. Yet, limitations are still conspicuous in light of a requisite fisheries management toolbox recommended as best policy practice (Costello et al., 2019). The amendment verifies that, in comparison, China aims to regulate territorial and EEZ fisheries more rigorously than its DWF expanding and operating overseas. Firstly, despite a level of regulatory consistency, China is operating in several sub-law carve-outs to continue promoting DWF suited to its economic-technological but not ecological modernization priorities (Fabinyi and Liu, 2014). It explains why TAC sees no near promise of implementation into the DWF sector, except for prolonged piloting programs in designated local fisheries since 2017 (MOA, 2017a). The statute continues to excuse DWF from any output limit, implying that Chinese vessels would make the most of their quotas granted by RFMOs and coastal countries. Secondly, DWF vessels are subject to bespoken landing, reporting, input restrictions, and at-sea transshipment regulations. They were initially exempted from the "two zeros" (vessel number and aggregate horsepower) growth policy (MOA, 2017b) until the 13th National Five-Year DWF Development Plan targeted a cap of 3,000 DWF vessels by 2020 and an amount of DWF enterprises fixed at the year 2016 level (MOA, 2017c). Still, existing DWF vessels are not required to abstain from destructive fishing practices, e.g., pair bottom trawls, stow nets, and Danish seine nets that have started phasing out of domestic waters (MOA, 2017b). Instead, a recent MARA amendment recognizes DWF's eligibility to continue existing trawling practices even though new trawlers are not allowed to be constructed (MARA, 2020b). And thirdly, China as a flag State does not hold legal entitlement to intervene in foreign coastal jurisdiction on operative matters, such as TAC, fishing gear, and onboard inspection at sea. Even if it intends to discharge certain "moral" accountability to the harvested area, nowadays $70 \%$ of the Chinese DWF fleet is composed of privately own vessels (Gutiérrez et al., 2020). Unlike stateowned enterprises' diligent execution of government policy, resource conservation is not an accepted priority of most profitdriven firms. About half of China's DWF vessels were found to concentrate in West and East Africa, overlapping with its BRI investment plan in some key fishing grounds and landing ports of the world (Pauly et al., 2014). However, like the EU, China was considered to have significantly underreported local catches to the FAO, including from both legal and illegal sources (Belhabib et al., 2015). A deficit in accountability to partner African countries triggered pervasive conflicts, legal violations, and even violence in distant waters where Chinese vessels operated from time to time (Li and Amer, 2015; Gutiérrez et al., 2020). The current input-based regulatory framework thus 
TABLE 1 | Amended Fisheries Law and sub-law provisions to address IUU fishing.

\begin{tabular}{|c|c|c|c|}
\hline $\begin{array}{l}\text { Management tools in amended } \\
\text { Fisheries Law (by provision) }\end{array}$ & Coastal State responsibilities & $\begin{array}{l}\text { Flag State } \\
\text { responsibilities }\end{array}$ & $\begin{array}{l}\text { Port and market } \\
\text { State responsibilities }\end{array}$ \\
\hline & $\begin{array}{l}\text { IUU fishing in territorial sea, } \\
\text { enclosed national EEZs }\end{array}$ & $\begin{array}{l}\text { IUU fishing in distant foreign } \\
\text { EEZs and the high seas }\end{array}$ & $\begin{array}{l}\text { Offloading, import and } \\
\text { export of IUU-caught } \\
\text { products }\end{array}$ \\
\hline $\begin{array}{l}\text { Input (e.g., vessels, engines and net } \\
\text { devices) restrictions (Art 9) }\end{array}$ & $\sqrt{ }$ & $\sqrt{ }$ (Separately in Art 30) & N.A. \\
\hline Total allowable catch (TAC) (Art 28) & $\sqrt{ }$ (Local pilot programs) $\quad \sqrt{ }$ (Bilateral fishery agreements) & N.A. & N.A. \\
\hline $\begin{array}{l}\text { Enterprise approval and annual audit } \\
\text { (Art 30) }\end{array}$ & $\sqrt{ }$ (By municipal and provincial fisheries bureaus) & $\begin{array}{l}\sqrt{ } \text { (By national fisheries } \\
\text { bureau) }\end{array}$ & N.A. \\
\hline Fishing permit (Art 31) & $\sqrt{ }$ (Paper or electronic) & & N.A. \\
\hline Fishing logbook (Art 33) & $\sqrt{ }$ (MLVs only in MARA, 2018, Art 8) & $\begin{array}{l}\sqrt{ } \text { (Electronic logbooks } \\
\text { encouraged in MARA, } \\
2018, \text { Art 51) }\end{array}$ & N.A. \\
\hline At-sea transshipment (Art 33) & $\sqrt{ }$ (Prohibited in MARA, 2018, Art 52) & $\begin{array}{l}\sqrt{ } \text { (MLVs } \\
\text { post-transshipment } \\
\text { logbook reporting in MARA, } \\
2018, \text { Art 50) }\end{array}$ & N.A. \\
\hline Vessel safety (Art 34) & $\sqrt{ }$ & $\begin{array}{l}\sqrt{ } \text { (Mandatory VMS in } \\
\text { MARA, 2020c, Art 35) }\end{array}$ & N.A. \\
\hline $\begin{array}{l}\text { Designated port entry, exit and } \\
\text { reporting (Arts } 35 \text { and 36) }\end{array}$ & $\sqrt{ }$ (MLVs only in MARA, 2019a) & $\sqrt{ }$ (Separately in Art 30) & $\begin{array}{l}\sqrt{ } \text { (RFMOs catch } \\
\text { certifications verified by } \\
\text { customs in MOA, 2010; } \\
\text { entry denied for IUU } \\
\text { vessels listed by } \\
\text { RFMOs in MARA, } \\
2019 c)\end{array}$ \\
\hline Product legality label (Arts 35 and 52) & $\sqrt{ }$ (MLVs only; local pilot programs) & $\times$ & $\begin{array}{l}\sqrt{ } \text { (purchase, } \\
\text { processing and sale of } \\
\text { illegally caught fish } \\
\text { prohibited) }\end{array}$ \\
\hline Onboard observer (Art 37) & $\sqrt{ }$ (MLVs only, national observers) & $\begin{array}{l}\sqrt{ } \text { (National and RFMOs } \\
\text { observers in MARA, 2020c, } \\
\text { Art 35) }\end{array}$ & N.A. \\
\hline $\begin{array}{l}\text { Prohibited fishing zones, seasons (Art } \\
\text { 41) }\end{array}$ & $\sqrt{ }$ & N.A. & N.A. \\
\hline $\begin{array}{l}\text { Prohibited fishing methods, gear, } \\
\text { species (Arts } 42 \text { and 48) }\end{array}$ & $\sqrt{ }$ & $\begin{array}{l}\sqrt{ }(\text { Coastal State and } \\
\text { RFMOs rules in MARA, } \\
2020 \text { c, Art 39) }\end{array}$ & N.A. \\
\hline $\begin{array}{l}\text { Personal blacklist and business } \\
\text { embargos (Art 74) }\end{array}$ & $\times$ & $\sqrt{ }$ & N.A. \\
\hline
\end{tabular}

$\sqrt{ }$, existent; $\times$, not-existent; N.A., not applicable.

Medium and large fishing vessels (MLVs) are between 12-24 $m$ and $24 \mathrm{~m}$ and above in length, respectively. Small fishing vessels are $12 \mathrm{~m}$ and below in length.

prompts us to explore innovative and effective countermeasures to assist in empowering China's fisheries management in the implementation phase afterward.

\section{ACTIONABLE RECOMMENDATIONS: COMBINING TRACEABILITY TECHNOLOGY AND MARKET LEVERAGES}

As identified in Figures 1-3 above, the universally reproached phenomenon of IUU fishing is no longer a strict taboo in China's political, legal, and academic circles. Since 2006, combating illegal capture fisheries has become more pronounced as a policy goal of the Ministry of Agriculture (MOA, renamed as MARA after March 2018) (MOA, 2006). Various promising indicators have emerged, such as ministerial circulars to target punishment (e.g., fines, blacklisting, and revocation of licenses) at DWF vessels and enterprises notified as lawbreakers from overseas (Shen and Huang, 2020). Proportional to its fisheries and economic size, China has gradually taken a critical move to respond to international norms and guidelines that call for collaborative efforts to eradicate IUU fishing. There is no lack of diversity in the regulatory tools the MARA has deliberated in the new statute. Implementation and enforcement coordination, nevertheless, remain the hardest crux in a renovated legal web to be. To complement and support traditional monitoring, surveillance, and control measures at sea, the transformative role of technological and marketplace-based measures warrants 
further exploring under the amended statute. There is potential for China to transition to government-led and even digital seafood traceability governance, so that stronger synergies are generated among different fisheries management tools acting on seafood legality and sustainability.

When canvassing the legal provisions above, we see the seeds of digital traceability governance already planted within. China's restrictive DWF policy has taken roots in the overarching textual design, where the most noteworthy include the mandated installment of VMS, a more extensive use of electronic fishing logs (to enable at least hourly reporting to the central Fisheries Bureau), and a blacklisting system to drive large fleets to perform higher transparency obligations (MARA, 2020a). Enhanced technological intelligence stands a chance to capture and transmit almost real-time complex fisheries profiles back to national authorities based faraway. Digital evidence, including VMS data and audio-visual images, once collected by government officials, carries the same legal weight as physical proof in prosecution and administrative sanctions (Art 54). Such modernization of DWF fleets means the industry can be expected to set the motion for strengthening industrial fishing operators' reporting and legal accountability to national and international jurisdictions. Furthermore, the envisioned legality labeling scheme operated at the point of market entry provides the safety valve for a point-topoint government-administered traceability system with regular inputs contributed by fishers and importers. In practice, two critical developments have unfolded to experiment the idea of government-led and digital seafood traceability within China.

For one thing, with its incomparable scale and pace in market digitalization, in 2018 China started a local governmentpioneered and electronic legality labeling scheme in Taizhou, Zhejiang Province. An initial set of 110 local fishing vessels tested the use of a mobile application (“渔港通”) to report all vessel movement and landing information automatically to nearshore governmental monitoring stations upon entry and exit (ZJOL, 2019). As a time-efficient and government-funded traceability program, it shows the promise to lower reporting costs and drive greater compliance motivation among local capture fishers. At the next stage, as the initiative does not explicitly exclude otherwise, Chinese DWF vessels and incoming foreign vessels may also be engaged in the information system, along with China's ratification of the Agreement on Port State Measures (PSMA) (FAO, 2009). In the long run, transnational inter-state cooperation in digital traceability governance can be explored in neighboring and distant foreign EEZs. Incidents of domestic fisheries law and international legal violations by Chinese DWF vessels necessitate increased data availability, access, and sharing to enable transparent fisheries monitoring across international borders (Park et al., 2020). Presumably, international supply chain cooperation toward common traceability goals can function as a stabilizer to political and economic relations in disputed fishing areas.

For another, in response to the food contamination crisis amid the ongoing COVID-19 pandemic, Beijing was the first to launch in October 2020, followed by more than ten provinces and cities in China, a cold chain and fully digital traceability platform for imported food products. Foreign refrigerated seafood cannot be sold to local consumers if product traceability information is not uploaded, verified, and accessible to both businesses and consumers through the unified online platform (Global Times, 2020). The implementation of traceability fundamentally hinges on the coordination mechanism established between local fisheries, Customs, and market surveillance agencies. This movement thus echoes precisely the new statute's call for interdepartmental monitoring and enforcement of the proposed legality labeling scheme (Article 52). Moreover, such policy innovation functions as vivid laboratory testing of how to strengthen institutional cooperation and integration to better inform China's future implementation of PSMA commitments (Wang and Tang, 2017).

Globally, seafood traceability governance is being enthusiastically embraced as an intelligent and cost-sharing management model by corporate and regulatory bodies. In several RFMOs, Europe, North America and more recently Japan (Japan National Diet, 2020), the transition from a paper-based to centralized digital traceability system is set in motion. Predominant exemplars of traceability governance include: (1) the EU's and several RFMOs' government-togovernment (G2G) catch documentation schemes (CDS) to trace catch movement from unloading through to the first point of sale; (2) the United States' government-to-business (G2B) import permit administered under the 2016 Seafood Import Monitoring Program to collect fisheries data through reporting and recordkeeping obligations ( $\mathrm{He}, 2018)$; and 3) various $\mathrm{B} 2 \mathrm{C}$ chain-of-custody certifications and ecolabels bestowed by thirdparty organizations such as the Marine Stewardship Council (Hosch, 2016). In March 2020, the Global Dialogue on Seafood Traceability (to which China's Aquatic Products Processing and Marketing Alliance is a member) publicized the first industrial standards to lead seafood companies into developing businessto-business (B2B) digital and interoperable traceability chain relations (GDST, 2020). A common backbone to those diverse traceability frameworks is a requisite and comparable group of Key Data Elements (i.e., who, where, what, and how fish were caught, processed, and distributed) that must be documented and transmitted throughout a chain (The Environmental Justice Foundation et al., 2020). Significant strides taken by communication and information technologies, such as smart contracts, the Internet of Things, Blockchain and Virtual Reality, have lent the key driving force (Fung Business Intelligence, 2017). The EU's government-led traceability paradigm has been found most instrumental in raising global alarms on IUU fishing vessels and their supportive states (Rafols, 2020), while contributing domestically to a "rather low" rate of mislabeling across "a considerable portion of the European seafood market" (Mariani et al., 2015).

The potential of seafood traceability governance can be further tapped by major consumer states like China to drive behavioral changes society-wide. Exporting to the United States and EU markets implies that Chinese companies must have already fulfilled advanced traceability requirements to secure market access. Currently, for the export-oriented sector, the MARA implements various CDS templates in conformity with the EU's, RFMOs' and Chile's traceability regulations at the 
border. For fish imports originating from Russia, a bilaterally agreed CDS exists to identify and eliminate any gray area of opportunities for foreign captured fish to be laundered through China's processing plants (MARA Government Service Platform). Moreover, the central Fisheries Bureau is steadily advancing China's ratification of the PSMA sooner rather than later, so that import controls will be considerably strengthened across all major points of entry along the national coastline (Woody, 2019). When traceability is combined with the use of the legality labeling scheme stipulated in Article 35, the government should not rest on simple label affixation to check the legal provenance of numerous local and foreign landings on Chinese ports. The recent COVID-19 pandemic permeating into the seafood market (e.g., salmon and shrimp packaging contamination scandals in northern China) demonstrates that the government's reactive ruling philosophy and paper-based working style have gone outmoded and resource-constrained. Making seafood supplies digitally traceable and trackable from any single link back to the origin will offer a more dynamic, efficient, and targeted solution to identify loopholes and legal liabilities. Hence, in designating ports for capture landings, the goal of traceability is expressly recognized in the draft revision (Art 36).

Given China's increasing seafood import dependency, governmental enforcement cooperation and information sharing should be seen as the next must-do. An undeniable challenge for combating IUU fishing is that millions of fishers and fish-processing workers rely on marine capture fisheries for their livelihoods in China. Nevertheless, law enforcement has been systematically compromised by the fragmented authority in fisheries management and local protectionism in coastal provinces (Su et al., 2020). To address such challenge headon, China has employed short-term economic incentives, such as vessel buyback, fishing license retirement, and other capacity-reduction subsidies (He, 2015). However, traceability implementation requires more long-term investment in education, technical upskilling, and infrastructure building in coastal communities to enable local fishers to mitigate the opportunity cost before they can reap real gains. Thus, the understaffed Fisheries Bureau warrants institutional capacity building to renovate human resources and enforcement equipment before it can take a central coordinator role in executing the traceability agenda.

Apart from technological and institutional breakthroughs, there is also the need to mainstream sustainability literacy in one of the world's biggest seafood markets. China's DWF expansion has generated worldwide concerns and alerts (Pauly et al., 2014; Gutiérrez et al., 2020). It comes with the imperative to ensure the transparency and legal credibility of the supply chain reaching numerous Chinese retailers and consumers. Currently, no specific international norm applies to processing and consumer State responsibilities against IUU fishing. Since port entry is considered the readiest point to cast IUU catches out of commerce, most existing traceability chains stop at the border and rarely engage downstream economic actors (e.g., processors, distributors, retailers, and final consumers) (He, 2018). In the way forward, a whole-of-government and society approach is highly warranted. The potential of China to develop a traceability system accountable to the public cannot be underestimated. While food safety remains a perennial domestic concern, accumulated consumer surveys highlight a growing preference among middleclass and younger generations for correctly labeled seafood by origin, species name, and even catching method (Marine Stewardship Council, 2018; GoalBlue, 2019). Hence, China can be well advised to leverage its massive online and offline trading outlets, highly efficient distributional, and Internet networks to engage all stakeholders in verifying seafood's legal and traceable qualities. Distant communication and feedback technologies, such as Quick Response codes, radio-frequency identification, and interactive mobile applications, have seen mounting popularity among technology-savvy chain stores, supermarkets, and younger consumer groups in contemporary China (Fung Business Intelligence, 2017). When legality and sustainability information is integrated into the reporting cycles of a plethora of e-commerce platforms such as Alibaba and JD.com, local consumers will be rewarded with the ease of making the most conscious and sensible purchasing decisions (Gutierrez and Khizhniak, 2019).

In the future, the seafood traceability system may even proceed to allow public or at least mixed portfolios in user access, for example, through permissioned consortium Blockchains (Blaha and Katafono, 2020), to avoid frauds and encourage a broader group of information contributors. The Beijingchampioned cold chain traceability platform discussed above is already open to the public, where consumers can proactively inquire and check product traceability information through WeChat and Alipay scan codes (China News, 2020). A fullchain traceability framework will only be as strong as its weakest link. Collaborative monitoring of information streams will be critical for ensuring data authenticity, integrity, and equal knowledge sharing. China's mission to manage the massive inflow and outflow of seafood through traceability mechanism is becoming essential to safeguard the sustainability of global fisheries, which has a long-lasting impact on people's food security, environmental, and social wellbeing.

\section{CONCLUSION}

The literature, policy, and legal surveys carried out above reinforce the emerging perception of China's rapidly transforming fisheries economy and its regulating environment. The proposed amendments to the Fisheries Law are a formal oath taken by the legislator to commit to a multitude of international and regional legal pacts against IUU fishing. While it may be regarded as an effort of internal adaption, we consider it the first important step for China to contribute globally to a sustainable seafood future for humanity. To empower the rule of law ahead, we recommend seafood traceability governance to help bring China's proposed anti-IUU policies into reality. Traceability governance should be operated as a transparent, interactive, and preventive strategy to consolidate all business and State parties' responsibilities for fisheries sustainability and the health of marine ecosystems. A steady progression from piloting 
projects to a truly nationwide framework will hinge upon the optimization of three main design and operation features below:

- An unbroken and immutable electronic information capture, transmission, and verification system linked to the nationwide fisheries legality label managed by the MARA and its local subsidiaries, to ensure traceable and trackable seafood movement inside and outside China, including under-regulated DWF and fishery processing entities.

- A precautionary and market-responsive approach to engaging public, private, and societal partnerships in adopting sustainable seafood production and consumption practices, incentivizing nationwide awareness and whistleblowing of IUU catches, especially from DWF and imported sources.

\section{REFERENCES}

Agnew, D. J., Pearce, J., Pramod, G., Peatman, T., Watson, R., and Beddington, J. R. (2009). Estimating the worldwide extent of illegal fishing. PLoS One 4:e4570. doi: 10.1371/journal.pone.0004570

Arthur, R., Heyworth, S., Pearce, J., and Sharkey, W. (2019). The Cost of Harmful Fishing Subsidies, International Institute for Environment and Development. London: IIED.

Belhabib, D., Sumaila, U. R., Lam, V. W. Y., Zeller, D., Billon, P. L., and Kane, E. A. (2015). Euros vs. Yuan: comparing European and Chinese Fishing Access in West Africa. PLoS One 3:e0118351. doi: 10.1371/journal.pone.01 18351

China Coast Guard. (2021). Typical Cases of Marine Fisheries Law Enforcement in 2020. http://www.ccg.gov.cn/2021/wqzf_0131/313.html (Published on Jan 31, 2021).

China News. (2020). Beijing has Established an Imported Cold Chain Food Traceability Platform Without Traceability Data, No Sales. https://www. chinanews.com/cj/2020/10-26/9322592.shtml (accessed on Oct 26, 2020).

Costello, C., Cao, L., Gelcich, L., Cisneros-Mata, M. A., Free, C. M., and Froehlich, H. E. (2019). The Future of Food from the Sea. Nature 588, 95-100. doi: 10.1038/s41586-020-2616-y

Fabinyi, M., and Liu, N. (2014). The Chinese policy and governance context for global fisheries. Ocean Coast. Manag. 96, 198-202. doi: 10.1073/pnas. 1616583114 doi: 10.1016/j.ocecoaman.2014.03.022

FAO. (2001). International Plan of Action to Deter, Prevent and Eliminate IUU Fishing, adopted on 23 June 2001. Rome: FAO.

FAO. (2009). Agreement on Port State Measures to Prevent, Deter and Eliminate IUU Fishing, Adopted on 22 November 2009, Effective from 5 June 2016. Rome: FAO.

FAO. (2018). Technical Guidelines on Methodologies and Indicators for the Estimation of the Magnitude and Impact of Illegal, Unreported and Unregulated (IUU) Fishing, Volume 2 - Guiding Principles and Approaches, Version 1. Rome: FAO.

FAO. (2020). The State of World Fisheries and Aquaculture: Sustainability in Action. Rome: FAO.

Blaha, F, and Katafono, A. O. K (2020). Blockchain Application in Seafood Value Chains. Rome: FAO.

Fung Business Intelligence. (2017). Navigating the New Retail Landscape in ChinaA Guide for Businesses. Oxford: Oxford University Press.

GDST. (2020). GDST 1.0 Standards. Available online at: https://traceabilitydialogue.org/gdst-1-0-materials/ (accessed on Feb, 2020).

Global Times. (2020). Cold-Chain Traceability to Favor Industry's Sustainable Growth. Available online at: https://www.globaltimes.cn/content/1206252. shtml\#:\$ \sim\$:text \penalty- $\backslash @ M=T h e \% 20$ State\%20Council\%2C\%20China' $\mathrm{s} \backslash$ penalty- $\backslash \mathrm{M} \% 20$ cabinet, through\%20imported\%20cold\%2Dchain\%20food (accessed on Nov 9, 2020).

GoalBlue. (2019). First-Tier Chinese Cities Sustainable Fishery Consumption Behaviour Survey Report. Available online at: http://goalblue.org/files/First-
- A collaborative inter-agency model of information sharing, regulatory coordination and legal enforcement to embed seafood traceability in multiple relevant legal regimes and across all responsible governmental agencies in China.

\section{AUTHOR CONTRIBUTIONS}

JH designed the study and drafted the abstract, main text, Table 1, and list of references. XZ conducted the literature, policy, and law surveys in both Chinese and English, drafted the Figures 1-3, and provided comments and suggestions on initial drafts. Both authors contributed to the article and approved the submitted version.

tier\%20Chinese\%20Cities\%20Sustainable\%20Fishery\%20Consumption\% 20Behavior\%20Survey\%20Report.pdf (accessed on 7 February, 2022).

Gutierrez, C., and Khizhniak, A. (2019). Alibaba Aims to Prevent Retail Fraud with Blockchain. https://www.altoros.com/blog/alibaba-aims-to-prevent-retailfraud-with-blockchain/ (accessed on Apr 27, 2019).

Gutiérrez, M., Daniels, A., Jobbins, G., Almazor, G., and Montenegro, C. (2020). China's Distant-Water Fishing Fleet: Size, Impact and Governance. London: Overseas Development Institute.

Hanson, A., Potts, J., Cui, H., Zou, L., Clarke, S., and Muldoon, G. (2000). Greening China's Fish and Fish Products Market Supply Chains. Winnipeg: International Institute for Sustainable Development.

He, J. (2015). Chinese public policy on fisheries subsidies: reconciling trade, environmental and food security stakes. Mar. Policy 56, 106-116. doi: 10.1016/ j.marpol.2014.12.021

He, J. (2016). Enhancing Chinese law and practice to combat illegal, unreported and unregulated fishing and trade. Asia Pac. J. Environ. Law 19, 4-28. doi: 10.4337/apjel.2016.01.01

He, J. (2018). From country-of-origin labelling (COOL) to seafood import monitoring program (SIMP): how far can seafood traceability rules go? Mar. Policy 96, 163-174. doi: 10.1016/j.marpol.2018. 08.003

Hosch, G. (2016). Trade Measures to Combat IUU Fishing: Comparative Analysis of Unilateral and Multilateral Approaches, International Centre for Trade and Sustainable Development. Geneva: IUU Fishing Index.

Japan National Diet. (2020). Domestic Trade of Specific Marine Animals and Plants Act, Adopted on 4 December 2020. Tokyo: Japan National diet.

Li, J., and Amer, R. (2015). Closing the net against IUU fishing in the South China Sea: china's practice and way forward. J. Int. Wildl. Law Policy 18, 139-164. doi: 10.1080/13880292.2015.1044799

Macfadyen, G., Caillart, B., and Agnew, D. (2016). Review of Studies Estimating Levels of IUU Fishing and the Methodologies Utilized. Rome: FAO.

Macfadyen, G., Hosch, G., Kaysser, N., and Tagziria, L. (2019). The IUU Fishing Index, Poseidon Aquatic Resource Management Ltd. \& Global Initiative Against Transnational Organized Crime. Geneva: IUU Fishing Index.

MARA. (2018). Provisions on the Administration of Fishery Licensing. Available online at: http://www.gov.cn/gongbao/content/2019/content_5368590.htm (adopted on 3 December 2018, effective from 1 January 2019).

MARA (2019a). Announcement on the Implementation of the Reporting System for Fishing Vessels Entering and Exiting Fishing Ports. Available online at: http://www.moa.gov.cn/nybgb/2019/201904/201906/t20190607_6316362.htm (published on 20 April 2019).

MARA. (2019b). Fisheries Law of the People's Republic of China, Revised Draft. http://www.gov.cn/hudong/2019-08/29/content_5425568.htm (published on 28 August 2019).

MARA. (2019c). Notice of Including IUU Vessels Identified by Relevant RFMOs under Fishery Port Control. Available online at: http://www.moa.gov. $\mathrm{cn} / \mathrm{nybgb} / 2019 / 201902 / 201905 / \mathrm{t} 20190518-6309470 . \mathrm{htm}$ (published on 5 January 2019). 
MARA. (2020a). Notice on Strengthening the Management of Distant-Water Fishing Vessels' Transhipment on the High Seas.Available online at: http://www.moa.gov. cn/gk/tzgg_1/tz/202005/t20200521_6344904.htm (published on 21 May 2020).

MARA. (2020b). Decision to Amend and Repeal Some Regulations and Regulatory Documents. Available online at: http://www.gov.cn/gongbao/content/2020/ content_5537932.htm (published on 8 July 2020).

MARA. (2020c). Provisions on the Administration of Distant-Water Fisheries, effective from 1 April 2020.

MARA Government Service Platform. MARA Government Service Platform. Available online at: http://zwfw.moa.gov.cn/ (accessed on 7 February 2022).

Mariani, S., Griffiths, A. M., Velasco, A., Kappel, K., Jérôme, M., and PerezMartin, R. I. (2015). Low Mislabeling Rates Indicate Marked Improvements in European Seafood Market Operations. Front. Ecol. Environ. 13:536-540. doi: $10.1890 / 150119$

Marine Stewardship Council. (2018). Sustainable Seafood and Chinese Market: MSC's China 5 Year Market Report.Shangai: MSC China Office.

MOA. (2006). Opinions on the Implementation of the Chinese Aquatic Biological Resources Conservation Action Plan. Available online at: http://www.moa.gov. cn/nybgb/2006/dliuq/201806/t20180616_6152302.htm (published on 20 June 2006).

MOA. (2010). Joint Announcement with the General Administration of Customs on the Application of Customs Clearance Certificates for Legal Fish Products to Certain Aquatic Products. Available online at: http://www.customs.gov. cn/customs/302249/302266/302267/357028/index.html (published on 1 June 2010).

MOA. (2017a). Letter to Carry Out the Pilot Allowable Catch Program for Marine Fishery Resources. Available online at: http://www.moa.gov.cn/govpublic/YYJ/ 201702/t20170223_5493787.htm (published on 13 February 2017).

MOA. (2017b). Notice to Further Strengthen the Management and Control of Domestic Fishing Vessels and the Implementation of Total Allowable Catch. Available online at: http://www.moa.gov.cn/nybgb/2017/derq/201712/ t20171227_6130861.htm (published on 20 February 2020).

MOA. (2017c). The 13th National Five-Year DWF Development Plan. Available online at: http://www.moa.gov.cn/gk/ghjh_1/201712/t20171227_6128624.htm

Packard Foundation. (2019). China Marine Strategy: Helping China Create an Ecological Civilization for its Ocean and Coasts. Available online at: https://www.packard.org/wp-content/uploads/2019/01/China-MarineStrategy_English.pdf (accessed on 7 February 2022).

Packard Foundation. (2020). Progress Toward Sustainable Seafood - By the Numbers. Available online at: https://oursharedseas.com/wp-content/uploads/ 2020/06/2020-Progress-Toward-Sustainable-Seafood-\%E2\%80\%93-By-theNumbers.pdf (accessed 7 February 2022).

Park, J., Lee, J., Seto, K., and Hochberg, T. (2020). Illuminating dark fishing fleets in North Korea. Sci. Adv. 6:eabb1197. doi: 10.1126/sciadv.abb1197

Pauly, D., Belhabib, D., Blomeyer, R., Cheung, W. W. W. L., Cisneros-Montemayor, A. M., and Copeland, D. (2014). China's distant-water fisheries in the 21st century. Fish Fish. 3, 474-488. doi: 10.1111/faf.12032

Pitcher, T., Kalikoski, D., Short, K., Varkey, D., and Pramod, G. (2009). An evaluation of progress in implementing ecosystem-based management of fisheries in 33 countries. Mar. Policy 33, 223-232. doi: 10.1016/j.marpol.2008. 06.002

Rafols, X. P. (2020). “The EU's global leadership in the fight against illegal, unreported, and unregulated fishing," in The European Union and Global Environmental Protection: Transforming Influence into Action, ed. M. C. Eritja (Oxfordshire: Routledge), 73-89. doi: 10.4324/9781003018513-5
Sadovy, Y., Tam, I., Muldoon, G., Le Clue, S., Botsford, E., and Shea, S. (2017). The Trade in Live Reef Food Fish - Going, Going, Gone. Hong Kong: ADM Capital Foundation and The University of Hong Kong, Hong Kong Special Administrative Region.

Shen, H., and Huang, S. (2020). China's policies and practice on combatting IUU in distant water fisheries. Aquac. Fish. 6, 27-34. doi: 10.1016/j.aaf.2020. 03.002

Su, S., Tang, Y., Chang, B., Zhu, W., and Chen, Y. (2020). Evolution of marine fisheries management in China from 1949 to 2019: how did China get here and where does China go next? Fish Fish. 21, 435-452. doi: 10.1111/faf.12439

Mallory, T. (2013). China's distant water fishing industry: evolving policies and implications. Mar. Policy 38, 99-108. doi: 10.1016/j.marpol.2012. 05.024

The Environmental Justice Foundation, Oceana, The Nature Conservancy, The Pew Charitable Trusts, and WWF. (2020). A Comparative Study of Key Data Elements in Import Control Schemes Aimed at Tackling Illegal, Unreported and Unregulated Fishing in the Top Three Seafood Markets.London: the European Union, the United States and Japan.

Trygg Mat Tracking. (2022). Combined IUU Fishing Vessel List. Available online at: https://iuu-vessels.org/. (accessed on 7 February 2022).

Wang, T., and Tang, Y. (2017). Effectiveness of the port state measures on combatting IUU Fishing and the influence of Port State Measures Agreement to China. J. Shanghai Ocean Univ. 26, 751-756.

Watson, R., and Tidd, A. (2018). Mapping nearly a century and a half of global marine fishing: 1869-2015. Mar. Policy 93, 171-177. doi: 10.1016/j.marpol. 2018.04.023

Woody, T. (2019). Available online at: https://chinadialogueocean.net/11135china-psma-illegal-fishing/. (accessed on Oct 25, 2019).

Xue, J. (2006). China's distant water fisheries and its response to flag state responsibilities. Mar. Policy 30, 651-658. doi: 10.1016/j.marpol.2005. 09.005

Zhang, X., and Vincent, A. (2020). China's Policies on Bottom Trawl Fisheries over Seven Decades (1949-2018). Mar. Policy 122:104256. doi: 10.1016/j.marpol. 2020.104256

ZJOL. (2019). Taizhou Builds a National Comprehensive Management and Reform Experimental Base for Fishing Vessels and Fishing Ports. Available online at: https://zjnews.zjol.com.cn/zjnews/tznews/201904/t20190417_9923199.shtml (published on 17 April 2019).

Conflict of Interest: The authors declare that the research was conducted in the absence of any commercial or financial relationships that could be construed as a potential conflict of interest.

Publisher's Note: All claims expressed in this article are solely those of the authors and do not necessarily represent those of their affiliated organizations, or those of the publisher, the editors and the reviewers. Any product that may be evaluated in this article, or claim that may be made by its manufacturer, is not guaranteed or endorsed by the publisher.

Copyright (C) 2022 He and Zhang. This is an open-access article distributed under the terms of the Creative Commons Attribution License (CC BY). The use, distribution or reproduction in other forums is permitted, provided the original author(s) and the copyright owner(s) are credited and that the original publication in this journal is cited, in accordance with accepted academic practice. No use, distribution or reproduction is permitted which does not comply with these terms. 